\title{
Akumulasi Logam Berat Seng (Zn) pada Akar dan Daun Lamun Enhalus acoroides di Perairan Pantai Sanur, Bali
}

\author{
I Komang Yopi Trio Santana ${ }^{*}$, Pande Gde Sasmita Julyantoro ${ }^{a}$, Ni Putu Putri Wijayantia \\ a Program Studi Manajemen Sumberdaya Perairan, Fakultas Kelautan dan Perikanan, Universitas Udayana, Bukit Jimbaran, Kabupaten \\ Badung, Provinsi Bali-Indonesia \\ * Penulis koresponden. Tel.: +62-856-551-465-57 \\ Alamat e-mail: yopitriosantana@yahoo.com
}

Diterima (received) 7 Juli 2018; disetujui (accepted) 2 Agustus 2018

\begin{abstract}
This study aims to determine the concentration of heavy metals $\mathrm{Zn}$ in sediments, roots and leaves of seagrass Enhalus acoroides and its ability in accumulating and translocating heavy metals in Sanur Beach waters area which conducted in February 2018. The method of this study was a descriptive method with the sampling station determined by using purposive sampling method which is conducted at 3 stations. This study use water quality and sediment samples and also samples of roots and leaves of seagrass Enhalus acoroides. Measurements some of water quality data were done by in situ while root and seagrass leaves samples were analyzed in UPT. Udayana University Analytical Laboratory using ICPE-9000. The results showed that the condition of the Sanur Beach waters quality in general is still suitable to support the life of the seagrass Enhalus acoroides in accordance with the Pergub Bali No. 16 of 2016 about environmental quality standards and standard criteria of environmental damage. The highest average concentration of $\mathrm{Zn}$ at the root was found at station 3 about $7.09 \mathrm{mg} / \mathrm{kg}$ and the lowest was $5.84 \mathrm{mg} / \mathrm{kg}$ at station 1 . The highest average of $\mathrm{Zn}$ concentration in the leaves was found at station 2 about $9.07 \mathrm{mg} / \mathrm{kg}$ and the lowest was $7.50 \mathrm{mg} / \mathrm{kg}$ at station 3. While the highest $\mathrm{Zn}$ concentration on sediment, was found at station 2 with value $12,27 \mathrm{mg} / \mathrm{kg}$ and lowest at station 3 with value $9.47 \mathrm{mg} / \mathrm{kg}$ of $\mathrm{Zn}$. The bioconcentration factor value (BCF) showed that the leaves and roots of the seagrass Enhalus acoroides can accumulate heavy metals $\mathrm{Zn}$ of 0.78 and 0.61 , respectively. Finally, calculation of translocation factor (TF) of 1.28 shows that the seagrass Enhalus acoroides is belong to the category of phytoextraction $(>1)$.
\end{abstract}

Keywords: Bioaccumulation; Heavy metal; Seagrass; Sanur Beach.

\begin{abstract}
Abstrak
Penelitian ini bertujuan untuk mengetahui konsentrasi logam berat Zn pada sedimen, akar dan daun lamun Enhalus acoroides serta kemampuannya dalam mengakumulasi dan mentranslokasi logam berat di kawasan perairan Pantai Sanur yang dilaksanakan pada bulan Pebruari 2018. Metode yang digunakan dalam penelitian ini adalah metode deskriptif dengan stasiun pengambilan sampel ditentukan dengan menggunakan metode purposive sampling yang dilakukan pada 3 stasiun. Sampling dalam penelitian ini meliputi sampling kualitas air, pengambilan sampel sedimen, akar dan daun lamun Enhalus acoroides. Pengukuran data kualitas air dilakukan secara insitu sedangkan analisis sampel akar dan daun lamun dilakukan di UPT. Laboratorium Analitik Universitas Udayana dengan menggunakan ICPE-9000. Hasil penelitian menunjukan bahwa kondisi kualitas perairan Pantai Sanur secara umum masih mampu menunjang kehidupan lamun Enhalus acoroides sesuai dengan Pergub Bali No. 16 Tahun 2016 tentang baku mutu lingkungan hidup dan kriteria baku kerusakan lingkungan hidup. Rata-rata kandungan logam berat Zn di akar tertingggi pada stasiun 3 yaitu sebesar 7,09 mg/kg dan terendah pada stasiun 1 sebesar 5,84 mg/kg. Rata-rata kandungan logam berat $\mathrm{Zn}$ di daun tertingggi pada stasiun 2 yaitu sebesar 9,07 $\mathrm{mg} / \mathrm{kg}$ dan terendah pada stasiun 3 yaitu sebesar 7,50 mg/kg. Sedangkan pada sedimen, kandungan logam berat $\mathrm{Zn}$ tertinggi pada stasiun 2 dengan nilai $12,27 \mathrm{mg} / \mathrm{kg}$ dan terendah pada stasiun 3 dengan nilai 9,47mg/kg. Nilai faktor biokonsentrasi (BCF) menunjukan bahwa daun dan akar lamun Enhalus acoroides dapat mengakumulasi logam berat Zn sebesar 0,78 dan 0,61. Hasil perhitungan Translocation Faktor (TF) sebesar 1,28 menunjukan lamun Enhalus acoroides termasuk kategori fitoekstraksi $(>1)$.
\end{abstract}




\section{Pendahuluan}

Indonesia adalah negara yang memiliki luas lautan sebesar duapertiga dari luas daratan. Dengan wilayah perairan yang luas, Indonesia memiliki kekayaan dan potensi keanekaragaman hayati laut yang sangat penting untuk dikelola dan dilestarikan dalam meningkatkan kesejahteraan hidup masyarakat. Penggunaan sumber daya alam yang diikuti dengan pemanfaatan teknologi dalam usaha mempermudah kebutuhan hidup manusia, selain menguntungkan akan mengakibatkan terjadinya pencemaran lingkungan.

Salah satu materi yang dapat menjadi bahan pencemar adalah jenis logam berat. Pencemaran logam berat merupakan permasalahan yang sangat serius untuk ditangani, karena hal ini dapat merugikan lingkungan dan ekosistem secara umum. Pencemaran logam berat terutama pada lingkungan perairan harus mendapat perhatian yang serius, karena bila terserap dan terakumulasi dalam tubuh manusia dapat mengganggu kesehatan diantaranya kerapuhan tulang, rusaknya kelenjar reproduksi, kerusakan otak, dan keracunan akut pada sistem saraf pusat (Amriani, 2011). Logam berat umumnya mempunyai sifat toksik dan berbahaya bagi organisme hidup, walaupun beberapa diantaranya diperlukan dalam jumlah kecil. Salah satu logam berat esensial yang dibutuhkan hampir semua organisme dalam jumlah sedikit yaitu logam berat Zn (Dahuri, 2003). Logam berat $\mathrm{Zn}$ dalam jumlah yang sangat sedikit dapat berperan dalam mendorong perkembangan pertumbuhan. Namun apabila konsentrasi logam berat $\mathrm{Zn}$ melebihi ambang batas yang ditentukan maka akan dapat menyebabkan terjadinya pencemaran yang berbaya bagi organisme perairan (Darmono, 1995).

Organisme yang banyak dijumpai dalam suatu perairan adalah lamun. Secara ekologis lamun mempunyai beberapa fungsi penting di daerah pesisir. Diantaranya merupakan produktivitas primer di perairan dangkal, sumber makanan penting bagi banyak organisme, sebagai produsen primer, perangkap sedimen dan berperan pada transfer nutrien (Dahuri, 2003). Menurut Astuti (2011) lamun dapat dijadikan bioindikator pencermaran logam berat karena dapat menyerap dan mengakumulasi bahan pencemar.
Pemanfaatan lamun sebagai bioindikator pencemaran logam berat telah dilakukan oleh beberapa peneliti antara lain Supriyantini, et al. (2016) meneliti kandungan logam berat Zn (Seng) pada lamun Enhalus acoroides di perairan Pantai Kartini Jepara. Hasil penelitian menunjukkan nilai akumulasi logam berat Zn (Seng) pada akar Enhalus acoroides berkisar antara 0,98-2,06 mg/kg dan pada daun 0,60-1,01 mg/kg.

Pantai Sanur yang terletak di Kecamatan Sanur, Kota Denpasar, Bali merupakan salah satu pantai yang memiliki keanekaragaman ekosistem tumbuhan lamun. Menurut Graha et al. (2016) Enhalus acoroides merupakan salah satu lamun yang banyak ditemukan di kawasan perairan Pantai Sanur. Kawasan Pantai Sanur dikenal sebagai kawasan pariwisata yang banyak dikunjungi tamu baik domestik maupun mancanegara. Selain sebagai tempat pariwisata, Pantai Sanur juga dijadikan sebagai tempat dermaga untuk kapal-kapal nelayan dan kapal boat yang diduga menjadi sumber logam berat Seng (Zn). Maka dari itu, perlunya dilakukan penelitian ini untuk mengetahui kandungan logam berat seng (Zn) pada lamun Enhalus acoroides di kawasan perairan Pantai Sanur, Bali.

\section{Metode Penelitian}

\subsection{Waktu dan Lokasi Penelitian}

Penelitian ini dilaksanakan pada bulan Pebruari 2018. Pengambilan sampel dilakukan di perairan Pantai Sanur, Bali pada 3 stasiun pengamatan (Gambar 1). Analisis sampel logam berat seng ( $\mathrm{Zn}$ ) di laksanakan di UPT. Laboratorium Analitik

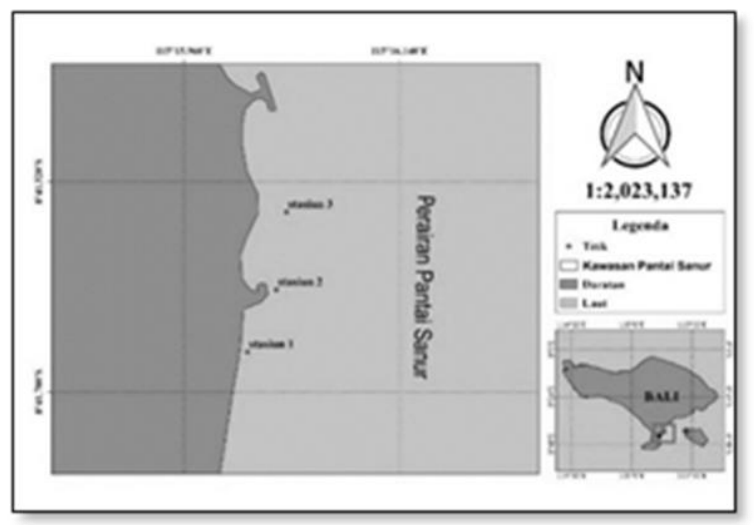

Gambar 1. Peta stasiun pengambilan sampel 
Universitas Udayana.

\subsection{Alat dan Bahan}

Alat yang digunakan dalam penelitian ini terdiri dari DO Meter (850045, American), $\mathrm{pH}$ Meter (CT6023, China), Refractometer (Master-53m, Jakarta), timbangan analitik (Esj 210-4b, Taiwan), ICP emission spectrometer (ICPE-9000, Japan), cool box (marina cooler 24s, Indonesia), pipet ukur, sekop kecil, gelas ukur, labu kjeldhal, heater (pemanas), termometer. Sedangkan untuk bahan yang digunakan terdiri dari aquades, sedimen, $\mathrm{HNO}_{3}$, $\mathrm{H}_{2} \mathrm{SO}_{4}$, akar dan daun lamun Enhalus acoroides.

\subsection{Metode Penelitian}

Metode penelitian yang digunakan adalah metode deskriptif, yaitu metode yang bertujuan untuk membuat gambaran atau lukisan secara sistematis, faktual dan akurat mengenai fakta-fakta, sifat-sifat hubungan antar fenomena yang diselidiki (Nazir, 2005). Stasiun pengambilan sampel ditentukan dengan menggunakan metode purposive sampling. Menurut Sugiyono (2011), Purposive sampling yaitu teknik penentuan stasiun sampling dengan pertimbangan tertentu. Penelitian ini menggunakan 3 stasiun penelitian dengan tiap stasiunnya dibagi menjadi 3 titik dengan jarak 30 $\mathrm{m}$ antar titik sampling. Stasiun 1 dekat dengan dermaga, stasiun 2 dekat dengan aktivitas pariwisata, dan stasiun 3 agak jauh dari aktivitas pariwisata.

\subsection{Prosedur Pengambilan Data Lapang}

\subsubsection{Kualitas Air}

Parameter kualitas air yang diukur konsentrasinya adalah suhu, $\mathrm{pH}, \mathrm{DO}$ dan salinitas. Pengukuran suhu air laut dilakukan dengan menggunakan thermometer. Pengukuran $\mathrm{pH}$ air laut dilakukan dengan menggunakan $\mathrm{pH}$ meter. Pengukuran salinitas dilakukan dengan menggunakan alat refraktometer. Pengukuran DO dilakukan dengan menggunakan DO meter.

\subsubsection{Sampel Sedimen}

Sampel sedimen diambil pada substrat padang lamun. Sedimen diambil menggunakan sekop sebanyak \pm 100 gram, kemudian dimasukan ke dalam plastik dan diberi label sesuai titiknya. Sampel sedimen disimpan dalam cool box.

\subsubsection{Sampel Lamun}

Sampel lamun Enhalus acoroides dikumpulkan pada saat surut. Pengambilan sampel lamun dilakukan dengan memilih lamun yang tua dengan ciri-ciri warna daun lebih pekat dan memiliki tekstur daun lebih keras. Pengambilan sampel lamun dilakukan dengan mencabut secara acak hingga akar-akarnya sebanyak 3 tegakan disetiap titiknya. Sampel lamun kemudian dibersihkan dari biota dan substrat yang menempel. Bagian akar dan daun lamun dipisahkan kemudian dimasukan kedalam kantong plastik sesuai dengan titik dan dimasukkan ke dalam cool box.

2.5 Analisis Kandungan Logam Berat pada Sediemn, Akar dan Daun Lamun Enhalus acoroides

Metode yang digunakan dalam analisis logam berat yaitu metode pengabuan basah menggunakan $\mathrm{HNO}_{3}$ dan $\mathrm{H}_{2} \mathrm{SO}_{4}$. Sampel akar, daun dan sedimen lamun Enhalus acoroides dikeringkan menggunakan oven dengan suhu $100{ }^{\circ} \mathrm{C}$ selama 1 jam. Sampel yang sudah kering kemudian diambil sebanyak $\pm 0,5$ gram dan dimasukan kedalam labu kjeldahl, kemudian ditambahkan $10 \mathrm{ml} \mathrm{H}_{2} \mathrm{SO}_{4}$. Dipanaskan perlahanlahan sampai larutan berwarna gelap, kemudian ditambahkan dan $10 \mathrm{ml} \mathrm{HNO}_{3}$ dan dilanjutkan pemanasan selama 5-10 menit sampai larutan tidak gelap lagi (semua zat organik telah teroksidasi). Diamkan larutan sampai dingin dan ditambah akuades sebanyak $50 \mathrm{ml}$. Larutan kemudian disaring dan dimasukan ke dalam botol sampel yang telah diberi label. Kemudian larutan diuji dengan menggunakan ICPE-9000.

\subsection{Analisa Data}

2.6.1. Perhitungan Bioakumulasi Logam Berat pada Lamun Enhalus acoroides

Analisa BCF dilakukan untuk mengetahui tingkat akumulasi logam berat $\mathrm{Zn}$ pada akar dan daun lamun Enhalus acoroides. Faktor biokonsentrasi dihitung dengan rumus (Ghosh dan Singh (2005) : 
$B C F=\frac{K b}{C w}$

dimana $B C F$ adalah faktor biokonsentrasi; $K b$ adalah kandungan logam berat pada akar/daun lamun; dan $C w$ adalah kandungan logam berat dalam sedimen. Menurut Baker (1981) kategori tanaman dapat dibagi menjadi 3 yaitu :

- Akumulator : apabila nilai BCF $>1$. Akumulator adalah tanaman yang dapat menimbun konsentrasi logam yang tinggi dalam jaringan tanamannya bahkan melebihi konsentrasi di dalam tanah.

- Excluder : apabila nilai BCF $<1$. Excluder adalah tanaman yang secara efektif mencegah logam berat memasuki area bagian atas tanaman, namun konsentrasi logam di sekitar area perakaran masih tinggi.

- Indikator : apabila nilai $\mathrm{BCF}=1$. Kategori tanaman sebagai bioindikator yaitu tanaman mentoleransi keberadaan konsentrasi logam dengan menghasilkan senyawa pengikat logam atau mengubah susunan logam dengan menyimpan logam pada bagian yang tidak sensitif.

\subsubsection{Translocation Factor (TF)}

Analisa TF digunakan untuk menghitung proses translokasi logam berat $\mathrm{Zn}$ dari akar ke daun. Perhitungan TF yang digunakan oleh Baker (1981) yaitu:

$T F=\frac{\text { Konsentrasi di daun }}{\text { Konsentrasi di akar }}$

Menurut Baker (1981) nilai TF memiliki kategori yaitu:

- $\mathrm{TF}>1$ : Mekanisme fitoekstraksi. Fitoekstraksi adalah proses penyerapan logam berat oleh akar tanaman yang kemudian di translokasikan menuju batang dan daun.

- $\mathrm{TF}<1$ : Mekanisme fitostabilisasi. Fitostabilisasi adalah proses yang dilakukan oleh tanaman untuk mentransformasi polutan di dalam tanah menjadi senyawa yang non toksik tanpa menyerap terlebih dahulu polutan tersebut kedalam tubuh tanaman. Hasil transformasi dari polutan tersebut tetap berada di dalam tanah tanaman menstabilkan polutan dalam tanah, sehingga membuat logam berat tidak berbahaya.

\subsubsection{Persentase Serapan}

Analisis persentase komposisi serapan logam berat Zn dihitung dengan menggunakan rumus sebagai berikut:

$$
(\%)=\frac{\text { Konsentrasi } \text { pada a } \text { arar atau daun }}{\text { Konsentasi } \text { pada sedimen }} \times 100
$$

\section{Hasil}

\subsection{Kualitas Perairan Pantai Sanur}

Berdasarkan hasil pengukuran data kualitas perairan di Pantai Sanur yang dilakukan secara insitu, pada setiap stasiunnya cenderung memiliki kisaran nilai yang sama. Hasil pengukuran DO tertinggi terletak pada stasiun 1 sebesar $6,3 \mathrm{mg} / 1$ dan pada stasiun 2 dan 3 memiliki DO yang sama yaitu sebesar 6,2 mg/l. Salinitas tertinggi di perairan Pantai Sanur terletak pada stasiun 1 yaitu sebesar 31,5 ppt dan terendah pada stasiun 2 dengan nilai 30,5 ppt. Berbanding terbalik dengan hasil parameter kualitas air lainnya, pada stasiun 2 mempunyai nilai suhu yang paling tinggi yaitu $27,3{ }^{\circ} \mathrm{C}$ dan yang terendah pada stasiun 1 sebesar $27{ }^{\circ} \mathrm{C}$. Pengukuran parameter $\mathrm{pH}$ di Pantai Sanur, hasil yang didapat menunjukkan $\mathrm{pH}$ tertinggi terletak pada stasiun 1 sebesar 8,2 dan $\mathrm{pH}$ terendah terletak pada stasiun 2 yaitu sebesar 8 . Secara rinci rata-rata hasil data kualitas perairan Pantai Sanur dapat dilihat pada Tabel 1.

Tabel 1.

Rata-rata Hasil Parameter Kualitas Air

\begin{tabular}{ccccc}
\hline \multicolumn{5}{c}{ Parameter Kualitas Air } \\
\hline Stasiun & $\begin{array}{c}\text { DO } \\
(\mathrm{mg} / \mathrm{l})\end{array}$ & $\begin{array}{c}\text { Salinitas } \\
(\mathrm{ppt})\end{array}$ & $\mathrm{pH}$ & $\begin{array}{c}\text { Suhu } \\
\left({ }^{\circ} \mathrm{C}\right)\end{array}$ \\
\hline 1 & 6,3 & 31,5 & 8,2 & 27 \\
2 & 6,2 & 30,5 & 8 & 27,3 \\
3 & 6,2 & 30,8 & 8,1 & 27,2 \\
\hline
\end{tabular}

3.2 Data Kandungan Logam Berat Seng ( $\mathrm{Zn}$ ) pada Sampel Akar, Daun, dan Sedimen Lamun Enhalus acoroides

Hasil pengukuran kandungan logam berat Zn pada sampel akar, daun dan sedimen lamun Enhalus acoroides memiliki nilai yang bervariasi pada setiap stasiunnya. Hasil analisis kandungan logam berat Zn pada sampel akar lamun yang tertinggi diperoleh pada stasiun 3 yaitu sebesar $7,09 \mathrm{mg} / \mathrm{kg}$ dan terendah pada stasiun 1 yaitu sebesar 5,84 mg/kg. Pada sampel daun lamun 
Enhalus acoroides yang dianalisis, hasil terendah diperoleh pada stasiun 3 yaitu sebesar 7,50 mg/kg dan stasiun 2 mendapatkan hasil yang paling tinggi yaitu 9,07 mg/kg. Nilai tertinggi kandungan logam berat $\mathrm{Zn}$ pada sampel sedimen lamun Enhalus acoroides terletak pada stasiun 2 yaitu sebesar $12,27 \mathrm{mg} / \mathrm{l}$ dan teredah terdapat pada stasiun 1 yaitu 9,47 mg/l. Secara rinci kandungan logam berat $\mathrm{Zn}$ pada sampel lamun Enhalus acoroides dapat dilihat pada Tabel 2.

3.3 Faktor Biokonsentrasi (BCF) Logam Berat Seng (Zn) pada Lamun Enhalus acoroides

Perhitungan Bioakumulasi logam berat $\mathrm{Zn}$ menggunakan rumus Ghosh dan Singh (2005). Bioakumulasi dihitung untuk mengetahui kemampuan lamun mengakumulasi logam berat melalui tingkat biokonsentrasi faktor (BCF). BCF akar dihitung dengan perbandingan antara kandungan logam berat $\mathrm{Zn}$ di akar dan kandungan logam berat $\mathrm{Zn}$ di sedimen, sedangkan $\mathrm{BCF}$ daun dihitung dengan perbandingan kandungan logam berat $\mathrm{Zn}$ pada daun dan kandungan logam berat $\mathrm{Zn}$ pada sedimen. Hasil perhitungan bioakumulasi logam berat $\mathrm{Zn}$ pada akar dan daun lamun Enhalus acoroides di perairan Pantai Sanur menunjukkan nilai BCF daun lebih besar daripada nilai BCF akar. Nilai BCF akar menunjukkan nilai yang hampir sama pada setiap stasiunnya. Nilai BCF akar tertinggi terletak pada stasiun 3 dengan nilai $0,63 \mathrm{mg} / \mathrm{kg}$ dan nilai BCF terendah terletak pada stasiun 2 yaitu sebesar 0,59 $\mathrm{mg} / \mathrm{kg}$. Selanjutnya nilai BCF daun tertinggi terdapat pada stasiun 1 dengan nilai $0,87 \mathrm{mg} / \mathrm{kg}$ dan yang terendah terletak pada stasiun 3 dengan nilai $0,67 \mathrm{mg} / \mathrm{kg}$. Secara rinci nilai $\mathrm{BCF}$ disetiap stasiunnya dapat dilihat pada Gambar 2.

\subsection{Faktor Translokasi (TF) Logam Berat Seng ( $\mathrm{Zn}$ ) pada Lamun Enhalus acoroides}

Perhitungan TF digunakan untuk menghitung translokasi logam berat $\mathrm{Zn}$ dari akar ke daun dengan menggunakan rumus Baker (1981). Hasil perhitungan TF logam berat $\mathrm{Zn}$ pada lamun Enhalus acoroides menunjukkan nilai yang hampir sama pada setiap stasiunnya. Nilai TF dari akar ke daun tertinggi terletak pada stasiun 1 dengan nilai $1,44 \mathrm{mg} / \mathrm{kg}$ dan nilai TF terendah terletak pada stasiun 3 yaitu $1,09 \mathrm{mg} / \mathrm{kg}$. Secara rinci nilai $\mathrm{TF}$ disetiap stasiunnya dapat dilihat pada Gambar 3.

\subsection{Komposisi Persentase Logam Berat Zn}

Berdasarkan hasil analisis persentase $\mathrm{Zn}$ setiap sampel terhadap kandungan yang ada di sedimen didapatkan persentase di akar tertinggi terletak pada stasiun 3 yaitu sebesar 63,04\% dan terendah terletak pada stasiun 2 yaitu $59,39 \%$. Persentase pada daun tertinggi terletak pada stasiun 1 sebesar $87,35 \%$ dan terendah terletak pada stasiun 3 sebesar $67,18 \%$. Secara rinci persentase logam berat Zn pada akar dan daun lamun Enhalus acoroides terhadap sedimennya dapat dilihat pada Gambar 4.

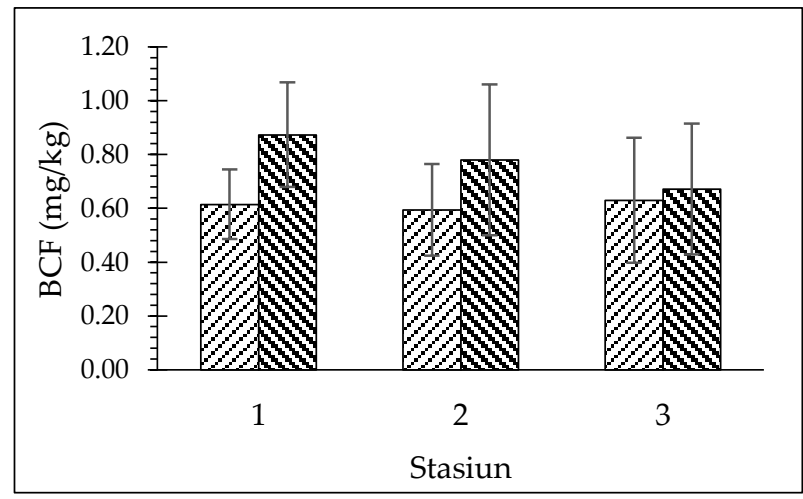

Gambar 2. Faktor biokonsentrasi (BCF) bagian akar (영 dan daun (㜽) lamun Enhalus acoroides

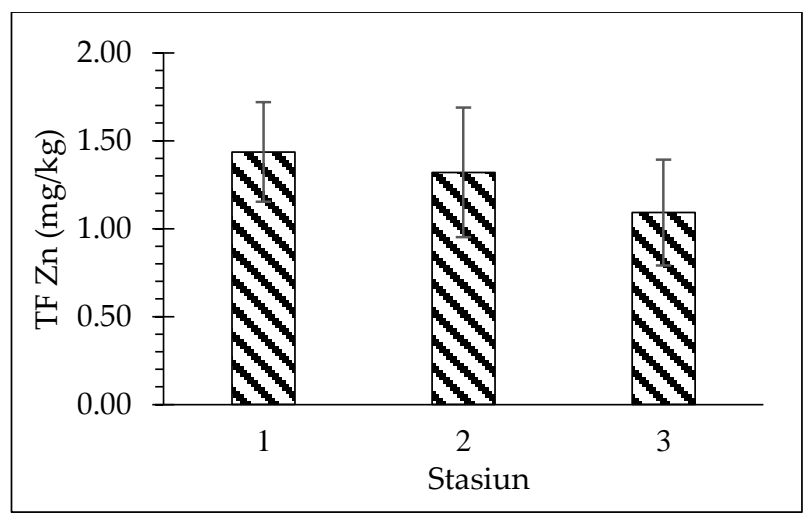

Gambar 3. Faktor translokasi (TF) logam berat Zn (『) pada lamun Enhalus acoroides

\section{Pembahasan}

\subsection{Kualitas Air di Pantai Sanur Berdasarkan Parameter Fisika dan Kimia}

Berdasarkan hasil pengukuran dapat dikatakan bahwa parameter kualitas air seperti DO, salinitas, $\mathrm{pH}$, dan suhu di perairan Pantai Sanur pada semua stasiun masih tergolong kategori baik. Hasil pengukuran kadar oksigen dalam perairan di area 
lamun diketahui rata-rata oksigen terlarut berkisar 6,2-6-3 mg/l. Secara keseluruhan, nilai oksigen terlarut memenuhi baku mutu optimal yang ditentukan. Menurut Pergub Bali No. 16 Tahun 2016 tentang baku mutu lingkungan hidup dan kriteria baku kerusakan lingkungan hidup, lamun dapat tumbuh dengan baik pada kisaran oksigen terlarut $>5 \mathrm{mg} / \mathrm{l}$. Hal ini juga didukung dengan pernyataan Effendi (2003), bahwa nilai DO di perairan sebaiknya tidak kurang dari $5 \mathrm{mg} / \mathrm{l}$ karena apabila nilai oksigen terlarut kurang dari 5 $\mathrm{mg} / \mathrm{l}$, maka hal tersebut akan menyebabkan efek yang kurang baik bagi seluruh organisme akuatik. Kondisi oksigen yang cukup baik diperairan dikarenakan adanya difusi oksigen berlangsung dengan baik dan intensitas cahaya matahari yang tembus kedasar perairan. Hal ini sangat mendukung untuk terjadinya proses fotosintesis oleh lamun dan organisme produsen lainnya, sehingga dari fotosintesis tersebut mengasilkan dan memperkaya gas oksigen dalam air.

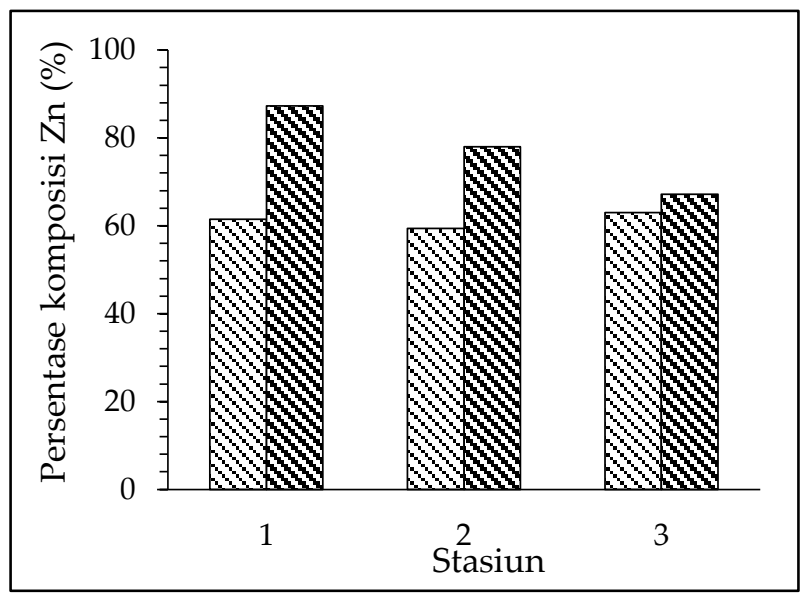

Gambar 4. Persentase komposisi Zn pada akar (\$) dan daun ( lamun Enhalus acoroides terhadap sedimen dimasing-masing stasiun penelitian.

Hasil pengukuran salinitas pada perairan Pantai Sanur di ketiga stasiun menunjukkan nilai salinitas yang sama sebesar 30 ppt. Dilihat dari nilai rata-ratanya bahwa nilai salinitas masih sesuai bagi kehidupan lamun secara optimal. Dahuri (2003) menyatakan bahwa spesies lamun memiliki toleransi yang berbeda-beda terhadap salinitas, namun sebagaian besar memiliki kisaran yang lebar, yaitu antara $10-40$ ppt. Nilai salinitas optimum untuk spesies lamun adalah $35 \mathrm{ppt}$.

Derajat keasaman di Pantai Sanur memiliki nilai rata-rata antara 8-8,2 dan tertinggi terletak pada stasiun 1 ( $\mathrm{pH}$ basa). Secara umum air laut memiliki $\mathrm{pH}$ yang sedikit basa. Sangat jarang dijumpai nilai $\mathrm{pH}$ yang asam karena di daerah pantai ada keseimbangan unsur-unsur karbonat dari kapur $\left(\mathrm{CaCO}_{3}\right)$. Terlebih di sepanjang Pantai Sanur terdapat karang penghalang yang mensuplai banyak kapur (Arthana, 2004). Nilai pH tersebut masih tergolong baik untuk pertumbuhan lamun. Menurut Pergub Bali No. 16 Tahun 2016 tentang baku mutu lingkungan hidup dan kriteria baku kerusakan lingkungan hidup memiliki kisaran derajat keasaman sebesar 7-8,5. Phillip dan Menez (1988) menyatakan kisaran $\mathrm{pH}$ yang baik untuk lamun adalah 7,5-8,5 karena pada saat kondisi $\mathrm{pH}$ berada pada kisaran tersebut maka ion bikarbonat yang dibutuhkan oleh lamun untuk fotosintesis dalam keadaan yang melimpah.

Suhu perairan Pantai Sanur pada semua stasiun diketahui memiliki nilai rata-rata sebesar $27,2{ }^{\circ} \mathrm{C}$. Dilihat dari rata-rata suhu perairan tersebut, dapat dikatakan bahwa suhu perairan Pantai Sanur masih layak bagi kehidupan lamun. Menurut Pergub Bali No. 16 Tahun 2016 tentang baku mutu lingkungan hidup dan kriteria baku kerusakan lingkungan hidup, kisaran suhu lamun dapat tumbuh dengan baik sebesar $28-30{ }^{\circ} \mathrm{C}$. Hal ini juga didukung oleh Effendi (2003) yang menyatakan bahwa perairan yang baik bagi organisme laut memiliki suhu berkisar $20-30{ }^{\circ} \mathrm{C}$. Lamun dapat mentolelir suhu perairan antara $20-36{ }^{\circ} \mathrm{C}$, tetapi suhu optimun untuk fotosintesis lamun berkisar 28-30 ํ C (Nybakken, 1993).

\subsection{Konsentrasi Logam Berat Seng (Zn) pada Sedimen}

Berdasarkan hasil pengamatan secara langsung, Pantai Sanur memiliki tipe sedimen berpasir berlumpur. Sangaji (1994) menyatakan bahwa Enhalus acoroides dominan hidup pada substrat berpasir dan pasir berlumpur dan kadang-kadang terdapat dasar yang terdiri dari campuran pecahan karang yang telah mati. Logam berat pada sedimen sering terjadi karena adanya dampak dari kegiatan-kegiatan manusia disekitarnya seperti kegiatan industri, pertanian atau rumah tangga. Sedimen merupakan kumpulan hasil rombakan batuan sekitarnya yang mempunyai kandungan logam berat yang ditentukan oleh mineralogi batuan asal. Didaerah yang dipengaruhi aktivitas manusia, kandungan logam berat yang terdapat dalam sedimen terdiri dari geokimia alami ditambah hasil aktivitas manusia. Kondisi ini merupakan input kontaminan logam berat masih 
cenderung dari darat (Arifin dan Fadhlina 2009). Secara umum logam berat di perairan dapat membahayakan kehidupan biota laut. Adanya akumulasi logam berat dalam sedimen dapat menimbulkan akumulasi pada tubuh biota yang hidup dan mencari makan di dalam air maupun disekitar sedimen. Akumulasi ini akan mencemari kehidupan biota laut dan selanjutnya akan berbahaya bagi manusia yang mengkonsumsinya.

Berdasarkan hasil analisis logam berat $\mathrm{Zn}$ menunjukan bahwa kandungan logam berat tertinggi dalam sedimen terletak pada stasiun 2 sebesar 12,27 mg/l. Hal ini dikarenakan stasiun 2 berdekatan dengan dermaga kapal dan aktivitas pariwisata. Razak (1987) menyatakan bahwa logam berat $\mathrm{Zn}$ digunakan untuk lapisan campuran logam, galvanisir, cat, baterai dan karet yang secara langsung dan tidak langsung berhubungan dengan aktivitas pelabuhan dan aktivitas penduduk. Diketahui bahwa logam berat Zn merupakan salah satu unsur yang digunakan sebagai bahan zat warna dalam cat kapal. Keberadaaan logam berat $\mathrm{Zn}$ juga dapat disebabkan karena adanya pelepasan pelapis anti fouling pada cat kapal yang berada di sekitar stasiun penelitian ke lingkungan perairan (Yin et al., 2015).

Nilai suhu pada stasiun 2 paling tinggi dibandingkan dengan stasiun lainnya tetapi memiliki nilai $\mathrm{pH}$ yang paling rendah. Effendi (2003) menyatakan bahwa peningkatan suhu akan meningkatkan reaksi kimia, evaporasi dan votilisasi. Suhu merupakan salah satu parameter untuk mempelajari transportasi dan penyebaran polutan yang masuk ke lingkungan laut (Mukhtasor, 2007). Hutagalung (1984) menambahkan bahwa kenaikan suhu tidak hanya akan meningkatkan metabolisme biota perairan, namun juga dapat meningkatkan toksisitas logam berat diperairan. Menurut Effendi (2003) derajat keasaman juga berpengaruh terhadap toksisitas suatu senyawa kimia, logam berat akan meningkat bila terjadi penurunan $\mathrm{pH}$. Hal ini dikarenakan kenaikan $\mathrm{pH}$ akan mengubah kestabilan dari bentuk karbonat menjadi hidroksida yang membentuk ikatan dengan partikel pada badan air sehingga akan mengendap membentuk lumpur. Pasifnya aktivitas manusia dan pelabuhan pada stasiun 1 menjadi salah satu faktor penyebab rendahnya konsentrasi logam berat $\mathrm{Zn}$ di sedimen, sehingga masukan logam berat $\mathrm{Zn}$ diduga hanya berasal dari $\mathrm{Zn}$ alami berada di perairan Pantai Sanur.

4.3 Konsentrasi Logam Berat Seng (Zn) pada Akar dan Daun Lamun Enhalus acoroides

Hasil analisis kandungan logam berat $\mathrm{Zn}$ pada akar dan daun lamun Enhalus acoroides di Pantai Sanur menunjukkan nilai yang bervariasi pada setiap stasiunnya. Kandungan logam berat Zn pada akar berkisar 5,84-7,09 mg/l. Adanya perbedaan kandungan logam berat $\mathrm{Zn}$ pada akar disetiap stasiun diduga disebabkan oleh adanya perbedaan kondisi lingkungan disetiap stasiunnya.

Tabel 2

Kandungan Logam Berat Zn pada Akar, daun dan Sedimen Lamun Enhalus acoroides di Pantai Sanur.

\begin{tabular}{ccccc}
\hline Stasiun & Titik & $\begin{array}{c}\text { Akar } \\
(\mathrm{mg} / \mathrm{kg})\end{array}$ & $\begin{array}{c}\text { Daun } \\
(\mathrm{mg} / \mathrm{kg})\end{array}$ & $\begin{array}{c}\text { Sedimen } \\
(\mathrm{mg} / \mathrm{kg})\end{array}$ \\
\hline \multirow{2}{*}{1} & 1 & 4,06 & 7,00 & 8,16 \\
& 2 & 6,68 & 7,74 & 11,26 \\
& 3 & 6,79 & 9,68 & 9,00 \\
& rata-rata & 5,84 & 8,14 & 9,47 \\
2 & 1 & 7,12 & 9,36 & 13,22 \\
& 2 & 6,39 & 10,81 & 14,58 \\
& 3 & 7,40 & 7,05 & 12,27 \\
& rata-rata & 6,97 & 9,07 & 14,65 \\
& 1 & 5,80 & 6,07 & 10,58
\end{tabular}


Pada stasiun 2 yang memiliki kandungan logam berat paling tinggi merupakan tempat yang digunakan untuk berbagai aktivitas seperti tempat dermaga kapal-kapal angkutan dan kapal nelayan, juga sebagai tempat pariwisata. Amin et al. (2011) menyatakan bahwa aktivitas pelabuhan dapat menjadi salah satu sumber pencemar logam berat diperairan sekitarnya. Dalam akar, logam berat Zn terakumulasi terutama pada jaringan endodermis dan eksodermis. Pada penelitian Tupan dan Azrianingsih (2016) diketahui bahwa jaringan tersebut memiliki peran penting dalam melindungi tanaman dari stres akibat logam berat.

Kandungan logam berat $\mathrm{Zn}$ pada daun berkisar antara 7,50-9,07 mg/l. Konsentrasi logam berat yang tinggi pada lamun disebabkan karena adanya proses penyerapan logam berat bersama dengan nutrien yang terjadi diakar dan daun. Tingginya kandungan logam berat pada daun menunjukkan bahwa daun merupakan akumulator utama logam berat diperairan. Konsetrasi logam berat Zn pada daun tidak hanya berasal dari mobilitas dari akar namun juga proses penyerapan oleh daun itu sendiri (Sugiyanto et al., 2016). Ahmad et al. (2015) menyatakan bahwa daun lamun memiliki kemampuan menyerap air dan zat terlarut termasuk logam berat dari perairan melalui stomata dan kutikula. Hal ini berbanding lurus dengan keberadaan pektin pada dinding sel lamun. Pektin dalam dinding sel lamun berperan penting dalam proses penyerapan ion. Kadar pektin dalam daun akan meningkat sesuai dengan pertambahan umur daun (Kuo dan Den Hartog, 2006). Lingby dan Brix (1982) menyatakan bahwa umur daun lamun mempengaruhi kadar logam beratnya, karena semakin tua tumbuhan lamun maka kemampuan daun pada lamun dalam menyerap logam berat akan meningkat.

Secara umum semua bagian morfologi lamun dapat digunakan sebagai bioakumulator dan bioindikator pencemaran logam berat yang berasal dari perairan dan sedimen (Ahmad et al., 2015). Fisiologi lamun menentukan kemampuan suatu bagian menyimpan atau mengakumulasi logam berat. Dalam tubuh lamun dapat terjadi transpor logam berat secara aktif atau pasif (Llagostera et al., 2011). Hal ini memungkinkan lamun menyerap dan mengakumulasi logam berat secara serentak karena seluruh tubuhnya terendam dalam air sehingga konsentrasi logam berat pada setiap bagian morfologi berbeda (Ahmad et al., 2015). Kontaminasi lamun oleh logam berat diduga akan semakin bertambah seiring dengan semakin berjalannya waktu (Nugraha, 2016).

\subsection{Faktor Biokonsentrasi (BCF) dan Faktor Translokasi} (TF) Logam Logam Berat Seng (Zn) pada Lamun Enhalus acoroides

Berdasarkan hasil perhitungan nilai faktor biokonsentrasi (BCF), akar lamun Enhalus acoroides memiliki nilai berkisar 0,59-0,63 $\mathrm{mg} / \mathrm{kg}$ dan daun lamun memiliki nilai berkisar 0,67-0,87 mg/kg, sedangkan rata-rata BCF logam berat Zn pada akar dan daun lamun Enhalus acoroides adalah 0,60 dan 0,75. Nilai BCF tertinggi pada lamun Enhalus acoroides terdapat pada daun di stasiun 3 dengan nilai $0,62 \mathrm{mg} / \mathrm{kg}$ dan nilai BCF terendah terletak pada akar di stasiun 2 dengan nilai $0,59 \mathrm{mg} / \mathrm{kg}$. Hasil perhitungan nilai BCF di lokasi penelitian membuktikan bahwa lamun Enhalus acoroides dapat mengakumulasi logam berat yang terdapat di perairan Pantai Sanur. Hal ini didukung oleh penelitian Supriyanti, et al. (2016) yang menyatakan bahwa lamun Enhalus acoroides mampu untuk menyerap dan mengakumulasi logam berat pada suatu perairan. Apabila dikategorikan menurut Baker (1981), Enhalus acoroides termasuk kedalam tanaman excluder terhadap logam berat $\mathrm{Zn}$ dengan nilai $\mathrm{BCF}<1$. Excluder adalah tanaman yang secara efektif mencegah logam berat memasuki area bagian atas tanaman, namun konsentrasi logam di sekitar area perakaran masih tinggi.

Hasil perhitungan nilai faktor translokasi (TF) logam berat Zn dari akar ke daun pada lamun Enhalus acoroides dari semua stasiun yakni berkisar antara 1,09-1,44 mg/kg. Perbedaan kemampuan translokasi dari setiap stasiun diduga disebabkan oleh perbedaan umur lamun yang berpengaruh pada kemampuan daya serap daunnya. Apabila dikategorikan menurut Baker (1981), Enhalus acoroides mempunyai mekanisme fitoekstraksi $(\mathrm{TF}>1)$ Fitoekstraksi adalah proses penyerapan logam berat oleh akar tanaman yang kemudian di translokasikan menuju batang dan daun.

\subsection{Persentase Komposisi Zn pada Akar dan Daun Lamun Enhalus acoroides terhadap Sedimennya}

Berdasarkan hasil analisis persentase komposisi logam berat $\mathrm{Zn}$, secara umum hasil penelitian ini menunjukan bahwa persentase komposisi $\mathrm{Zn}$ pada organ daun dan akar terhadap sedimen tampak 
tidak berbeda nyata pada masing-masing stasiun. Secara umum hasil penelitian menunjukan bahwa sekitar $67,18-87,35 \%$ tersimpan di daun dan sekitar 59,39-63,04\% tersimpan di akar.

Organ daun mempunyai persentase kandungan lebih tinggi daripada akar. Hal ini diduga karena berkaitan dengan luas permukaan bagian daun lamun yang lebih besar dari akar sehingga memungkinkan semakin banyaknya dinding sel tanaman yang menyerap ion (Supriyantini et al., 2016). Sugiyanto et al. (2016) menyatakan konsetrasi logam berat $\mathrm{Zn}$ pada daun tidak hanya berasal dari mobilitas dari akar namun juga proses penyerapan oleh daun itu sendiri.

\section{Kesimpulan dan Saran}

\subsection{Kesimpulan}

Kandungan rata-rata logam berat Zn pada akar dan daun lamun Enhalus acoroides masing-masing berkisar antara 5,84-7,09 mg/kg dan 7,50-9,07 $\mathrm{mg} / \mathrm{kg}$. Kandungan rata-rata pada sedimen berkisar antara 9,47-12,27 mg/kg. Kondisi kualitas perairan Pantai Sanur secara umum masih mampu menunjang kehidupan Lamun Enhalus acoroides sesuai dengan Pergub Bali No. 16 Tahun 2016 tentang baku mutu lingkungan hidup dan kriteria baku kerusakan lingkungan hidup. Nilai BCF menunjukkan bahwa daun dan akar lamun Enhalus acoroides merupakan tumbuhan dengan kategori excluder dengan mengakumulasi logam berat $\mathrm{Zn}$ sebesar 0,78 dan 0,61 (BCF<1). Nilai TF rata-rata keseluruhan logam berat $\mathrm{Zn}$ dari akar ke daun menunjukkan bahwa lamun Enhalus acoroides mempunyai mekanisme fitoekstraksi dengan nilai 1,28 (TF $>1)$. Persentase komposisi Zn pada akar dan daun terhadap sedimen menunjukan bahwa sekitar 67,18-87,35\% tersimpan di daun dan sekitar 59,39-63,04\% tersimpan di akar.

\subsection{Saran}

Penelitian ini baru menganalisis kandungan logam berat Zn pada akar, daun dan sedimen lamun berdasarkan satu kali pengambilan data, sehingga perlu adanya penelitian lebih lanjut untuk mengukur semua jenis kandungan logam berat pada semua bagian tumbuhan lamun dan perairan untuk mengetahui keseluruhan akumulasi logam berat pada lamun. Perlu adanya penelitian lebih lanjut mengenai potensi semua jenis lamun yang dapat mengakumulasi logam berat di perairan
Pantai Sanur. Sehingga fungsi lamun nantinya dapat menjadi bahan pertimbangan untuk memantau dan mengurangi perkembangan pencemaran logam berat di perairan Pantai Sanur.

\section{Ucapan terimakasih}

Penulis mengucapakan banyak terimakasih kepada seluruh keluarga besar Fakultas Kelautan dan Perikanan Universitas Udayana dan UPT. Laboratorium Analitik Universitas Udayana serta dosen pembimbing dan penguji yang telah membimbing, memberikan saran, bantuan dan masukan dalam penelitian dan penulisan jurnal ini.

\section{Daftar Pustaka}

Ahmad, F., Azman, S., Mohd Said, M. I., \& Baloo, L. (2015). Tropical seagrass as a bioindicator of metal accumulation. Sains malaysiana, 44(2), 203-210.

Amin, B., Afriyani, F., \& Saputra, M. A. (2011). Distribusi Spasial logam berat $\mathrm{Pb}$ dan $\mathrm{Cu}$ pada sedimen dan Air Laut Permukaan di Perairan Tanjung Buton Kabupaten siak provinsi riau. Jurnal teknologi, 11(1), $1-8$.

Amriani. (2011). Bioakumulasi Logam Berat Timbal (Pb) dan Seng (Zn) pada Kerang Darah (Anadara Granosa L.) dan Kerang Bakau (Polymesoda Bengalensis L.) di Perairan Teluk Kendari. Tesis. Semarang, Indonesia: Universitas Diponegoro.

Arifin, Z., \& Fadhlina, D. (2009). Fraksi logam berat Pb, $\mathrm{Cd}, \mathrm{Cu}$ dan $\mathrm{Zn}$ dalam sedimen dan biovaliabilitasnya bagi biota di periaran Teluk Jakarta. Ilmu Kelautan, 14(1), 27-32.

Arthana, I. W. (2004). Jenis dan kerapatan Padang lamun di Pantai Sanur Bali, Denpasar: Universitas Udayana. Jurnal Lingkungan Hidup Bumi Lestari, 2(5), 68-76.

Astuti, W. (2011). Kandungan Logam Berat Pb (Timbal) pada Lamun Enhalus acoroides di Pesisir Teluk Ambon. (elibrary.ub.ac.id/handle/123456789) [Diakses: 30 Oktober 2017].

Baker, A. J. M. (1981). Accumulator and excludersstrategic in the response of plants to heavy metals. Journal of Plant Nutrition, 3(1-4), 643-654.

Connel, D. W., \& Miller, G. J. (1995). Pollution Chemistry Ecotoxicology. Dalam Koestoer, Y (Terj.) Kimia dan Ekotoksikologi Pencemaran. Jakarta, Indonesia: Universitas Indonesia Press.

Dahuri, R. (2003). Keanekaragaman Hayati Laut Aset Berkelanjutan Pembangunan Indonesia. Jakarta, Indonesia: Gramedia Pustaka. 
Darmono. (1995). Logam Dalam Sistem Biologi Makhluk Hidup. Jakarta, Indonesia: Universitas Indonesia Press.

Effendi, H. (2003). Telaah Kualitas Air Bagi Pengelolaan Sumberdaya dan Lingkungan Perairan. Yogyakarta, Indonesia: Kanisius.

Ghosh, M \& Singh, S.P. (2005). Comparative uptake and phytoextraction study of soil induced chromium by accumulator and high biomass weed species. Applied ecology and environmetal research, 3(2), 67-79.

Hutagalung, H. P. (1991). Pencemaran Laut Oleh Logam Berat Dalam Status Pencemaran Laut di Indonesia dan Teknik Pemantauannya. Jakarta: Puslitbang Oseanologi-LIPI.

Pergub Bali. (2016). Peraturan Gubenur Bali No. 16 tahun 2016 Tentang baku Mutu lingkungan Hidup dan Kriteria Baku Mutu Kerusakan Lingkungan hidup. DenpasarBali: Pemerintah Provinsi Bali.

Kuo, J., \& Den-Hatog, C. 2006. Seagrass Morphology, Anatomy, and Ultrastructure. Dordrecht: Springer. 5187 hal.

Lingby, J. E., \& Brix, H. (1982). Uptake and Translocation of Phosphorus in Eelgrass (Zostera marina). Marine Biology, 90, 111-116.

Llagostera, I., Perez, M., \& Romero, J. (2011). Trace metal content in the seagrass Cymodocea nodosa: differential accumulation in plant organs. Aquat. Bot., 95, 124-128.

Mukhtasor. (2007). Pencemaran Pesisir dan Laut. Jakarta, Indonesia: Pradya Paramita.

Nugraha, A. H. (2016). Respon fisiologis lamun Thalassia hemprichii dan Cymodocea rotundata terhadap tekanan antropogenik di Gugusan Pulau Pari Kepulauan Seribu. Tesis. Bogor, Indonesia: Institut Pertanian Bogor.
Phillips, R. C, \& Menez, E. G. (1988). Seagrass. Washington DC, USA: Smith Sonian Institution Press.

Radulescu, C., Stihi, C., Popescu, I. V., Dulama, I. D., Chelarescu, E. D., \& Chilian, A. (2013). Heavy metal accumulation and translocation in different parts of Brassica oleracea L. Rom. J. Phys., 58(9), 1337-1354.

Razak, H. (1987). Pengaruh logam berat terhadap lingkungan.Warta Oseana, 6(2), 9-15.

Sangaji, F. (1994). Pengaruh Sedimen dasar terhadap Penyebaran, Kepadatan, Keanekaragaman dan Pertumbuhan Padang Lamun di Laut Sekitar Pulau Barang Lompo. Tesis. Ujung Pandang, Indonesia: Pascasarjana Universitas Hasanudin.

Sugiyanto, R. A. N., Yona, D., \& Kasitowati, R. D. (2016). Analisis akumulasi logam berat timbal $(\mathrm{Pb})$ dan kadmium (Cd) pada lamun Enhalus acoroides sebagai agen fitoremediasi di Pantai Paciran Lamongan. Seminar Nasional Perikanan dan Kelautan VI, Fakultas Perikanan dan Ilmu Kelautan, Universitas Brawijaya malang. 449-455.

Supriyanti, E., Sedjati, S., \& Nurfadhli, Z. (2016). Akumulasi logam berat $\mathrm{Zn}$ (seng) pada lamun Enhalus acoroides dan Thalassian hemprichii di peraiaran Pantai Kartini Jepara. Buletin Oseanografi marina, 5(1), 14-20.

Tupan, C. I., \& Azrianingsih, R. (2016). Accumulation and deposition of lead heavy metal in the tissue of roots, rhizomes and leaves of seagrass Thalassia hemprichii (Monocotyledoneae, Hydrocharitaceae). Bioflux, 9(3), 580-589.

Yin, S., Feng, C., Li, Y., Yin, L., \& Shen Z. (2015). Heavy metal Pollution in the surface water of the yangtze Estuary: A 5-year follow-up study, Chemosphere, 138, 718-725. 